\title{
EMOTIONAL NEEDS ASSESSMENT OF ATTRIBUTES OF ALTERNATIVE POWER GENERATOR TO KUALA DISTRICT COMMUNITIES
}

\author{
Rosnani Ginting ${ }^{1,3)}$, Juliza Hidayati ${ }^{1,4)}$, Muhammad Zulfin ${ }^{2,5)}$ and Alfin Fauzi Malik ${ }^{1,6}$ \\ ${ }^{1)}$ Department of Industrial Engineering, Universitas Sumatera Utara \\ ${ }^{2)}$ Department of Electrical Engineering, Universitas Sumatera Utara \\ e-mail: ${ }^{3}$ rosnani_usu@yahoo.co.id, ${ }^{4}$ rivaijuliza@gmail.com, ${ }^{5}$ zulfinmhd@gmail.com, ${ }^{6}$ alfinfm@gmail.com
}

\begin{abstract}
ABSTRAK
Tujuan penelitian ini untuk mengidentifikasi kebutuhan teknis dan persyaratan di Kabupaten Langkat terkait dengan variabel desain pembangkit listrik, diuraikan dalam bentuk kuesioner fungsional dan non-fungsional. Atribut produk pembangkit listrik berdasarkan hasil distribusi kuesioner kano mengungkapkan bahwa atribut harga dan daya tahan generator berada dalam kategori menarik. sedangkan atribut kemudahan pengoperasian termasuk dalam kategori satu dimensi. sementara estetika adalah satu-satunya atribut yang termasuk dalam kategori indifferent
\end{abstract}

Kata kunci: Kano model, Quality Function Deployement Energi Alternatif, kebutuhan Pelanggan.

\section{ABSTRACT}

The purpose of this study to identify the technical needs and requirements of in Langkat District related to the power generation design variables, outlined in the form of a functional and non-functioning questionnaires. The power plant product attributes based on the results of the kano questionnaire distribution revealed that the price attribute and durability of the generator was in the attractive category. while the attributes of ease of operation are included in the one dimensional category. while aesthetics is the only attribute that falls into the indifferent category.

Keywords: Kano model, Quality Function Deployement, Alternative Energy, Customer's need.

\section{INTRODUCTION}

Today, we are increasingly aware of the importance and the benefits of alternative energy sources. Energy, and especially electricity, is more sought after, more valuable and more expensive in modern times. As conventional energy sources are used at high speeds, people are increasingly forced to switch to renewable alternatives [1]. When we talk about alternative energy, we are referring to all energy derived from sources other than traditional energy [2].

Alternative energy is any energy that might not come from fossil fuels, and is a challenge as well as an opportunity. Alternative energy naturally finds endless sources of energy, such as wind, water, or sun. [3]. Alternative energy causes little or no pollution. Although around 176 countries now have clean energy policies, the world still relies heavily on oil, gas and coal.

In some countries, several alternative energy projects have been launched to reduce our reliance on traditional fossil fuels, such as oil [4]. In fact, in many developing countries, energy demand is increasing, resulting in continuous power outages or even complete supply cessation.

The Regulatory and renewable energy policy framework in recent years, sustainable energy development has sought to include the environment as one of the elements of competition that contributes to the economic and social development of the population. 2019 is an important year for renewable energy development worldwide, in many countries there is a significant increase in installed capacity with renewable resources.

In the developed world itself, alternative energy has been widely used in domestic life Alternative energy consumption has not gone smoothly in our country. There are many examples of alternative energy that we can use to replace our primary energy sources. Most of the energy used in Indonesia is produced by burning oil, coal and gas. By using 
non-renewable energy sources, humans cause pollution from emission to atmospheric carbon dioxide (CO2) and other greenhouse gases. Carbon dioxide is a major contributor to global warming, which already has unintended consequences.

Renewable energy is changing the global energy scenario [5]. Innovations in alternative technologies are revolutionizing the market and many new research centers, companies and companies are developing systems that can help reduce carbonization of the economy, and while many of them are not commercially viable, they are rapidly expanding.

The major goal of this paper was intended to identify and survey the technical needs and requirements that are collected from the specialist team and community of generator customers in Langkat District related to power generation design variables, outlined in the form of a functional and non-functioning questionnaires. Finally, the findings of this study are an important base to propose the design development of the prototype of power plant generator.

\section{Kano Model}

The Kano has been widely applied for analysis the customer needs, decision making, and other purposes [6]. Basically, the Kano classifies customer requirements or product variables into several sub-categories based on the level of customer satisfaction to fulfil the customer needs [7]. Kano developed by Professor Noriaki Kano in the 1980s at a University in Tokyo, Japan. The Kano model is a quality management method aimed at improving processes, products, or services. Kano based on customer needs, i.e., what customers need, and how you achieve customer satisfaction [8].

Figure 1 presents the fundamental of Kano concepts. There are 5 categories of quality factors that must be, one dimensional, attractive, carefree and, in turn, each with different characteristics and levels of influence on the user. Categories must be the basic quality factor that must be present in the product or service as they are the primary function of the product [9].

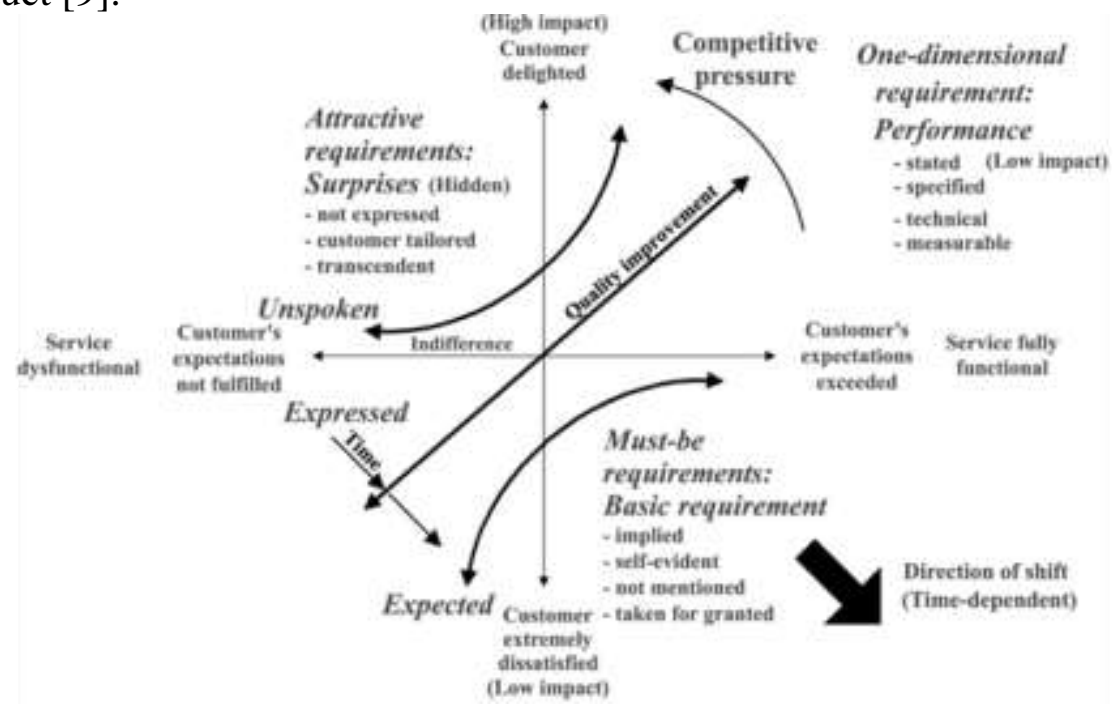

Figure 1. Kano Diagram

If the categorized attribute must not be met, the customer will immediately be dissatisfied. One dimension is the need for a product or service that will satisfy the user and otherwise the user will be disappointed with the absence of this attribute. Unlike onedimensional categories, attractive categories will not result in decreased satisfaction levels if these attributes are not present in the product. Another category is that indifference will not cause any reaction to the consumer and instead a category that will cause dissatisfaction [10]. 
The use of Kano is proposed because researchers see the importance of understanding the approach to the emotional desires of users in supporting the development of alternative energy use, which has never been done before.

\section{Quality Function Deployment}

Lai, et al (2012), argued that QFD is a general concept that provides the rules for translating customer requirements into technical specifications. QFD is implemented as a multi-phase process, offering the greatest potential for significant benefits (Naseri, 2014). QFD is a comprehensive rule and deserves to be a pillar that can be combined with other design benefits due to its strengths. Mazur (2000) said that the concept of QFD is a clear understanding of what customer's need. Miguel (2007), argues that QFD rules focus on customer-oriented product development (Hoyle, et al, 2007). Many studies have shown that to meet customer specifications, QFD rules must be applied during product planning stages to ensure awareness of the importance of customer voice (Yang, et al., 2011). Bouchereau and Rowldan (2000), argued that the starting point of the QFD is customer preference, though often cited but measurable. These requirements will then be changed to technical specifications.

A complete QFD process requires at least four phases to be developed that extend the entire development life of the system. Each of the four phases of the QFD process uses a matrix to translate customer needs from the initial planning stage through production control. The QFD method is known by a few names, the most common being the House of Quality (see Figure 2).

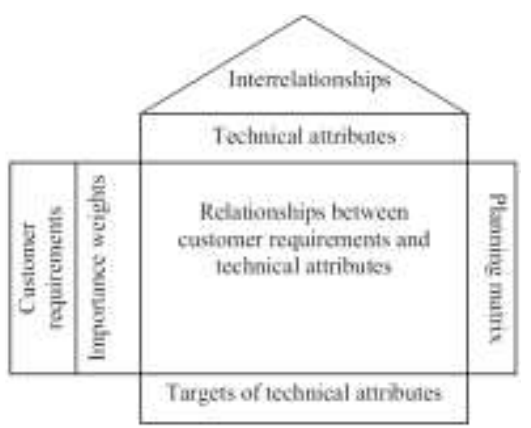

Figure 2. House of QFD (Cohen, 1995)

Also, Lai et al. (2012) found that QFDs have significant benefits that integrate customer and technical requirements for designers and manufacturers to help companies provide better products, increase their competitiveness in the market, and increase customer satisfaction. Poel (2007) argued that the main aim of QFD is to translate customer target values into product engineering features. By systematically and quantitatively adopting the relationship between customer demand and engineering features, the most promising engineering features are to enhance customer satisfaction and set the target value.

\section{METHODS}

The data were obtained from interviews with the expert team and the community of generator customers in Langkat District. Primary data are collected by direct observation or measurement, including preliminary questionnaire data, open questionnaire data, interest and satisfaction questionnaire data, and Kano questionnaire data. Kano's questionnaire consists of two fold question, functional question and dysfunctional question. The functional question asks the customer attitudes if technical respond is well functioning. Otherwise, dysfunctional question is a question that asks the customer perception if the technical respond does not work or does not exist. 
Langkat regency, especially the Kuala sub-district was a place for data collecting. This region is surrounded by 26 large and small rivers, through districts and villages, between the rivers: Wampu, Batang Attangan, Lapan, and Besitang river. Generally, these rivers are used for irrigation and transportation. Based on the natural state of Langkat Regency, researchers are looking at potential alternative energy development. Alternative energy is a term that refers to all energy that can be used to replace conventional fuels without the unintended consequences. Generally, the term is used to reduce the use of hydrocarbon fuels that cause environmental damage due to high carbon dioxide emissions, which contributes significantly to global warming based on the Intergovernmental Panel on Climate Change.

\section{RESULT AND DISCUSSION}

\section{Quality Function Deployment Analysis}

Data collection was done by surveying the questionnaire to the respondents, which is distributed in two phases. First is open questionnaire, to ask the respondent of the expectation of power plant in the Kuala sub - district. Second one is Kano questionnaire. Determination of the number of respondents is based on the sampling method of total sampling (population research). Table 1 shows the customer requirement, as follows.

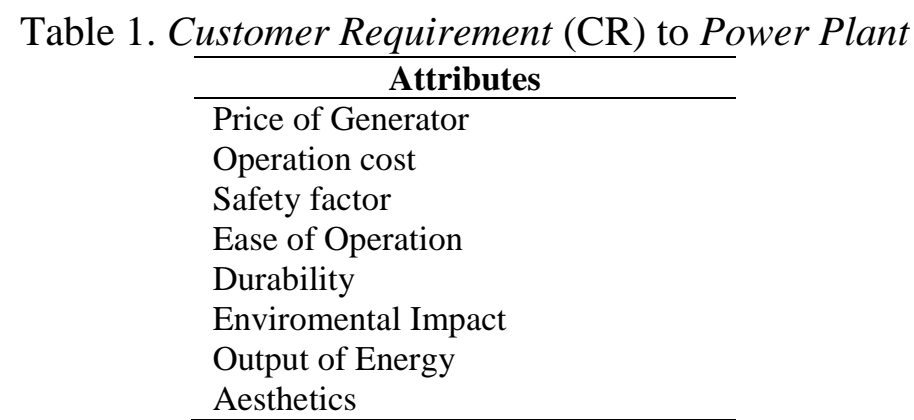

The data from the previous steps are organized into the HOQ matrix. Figure 3 shows House of of alternative power generation.

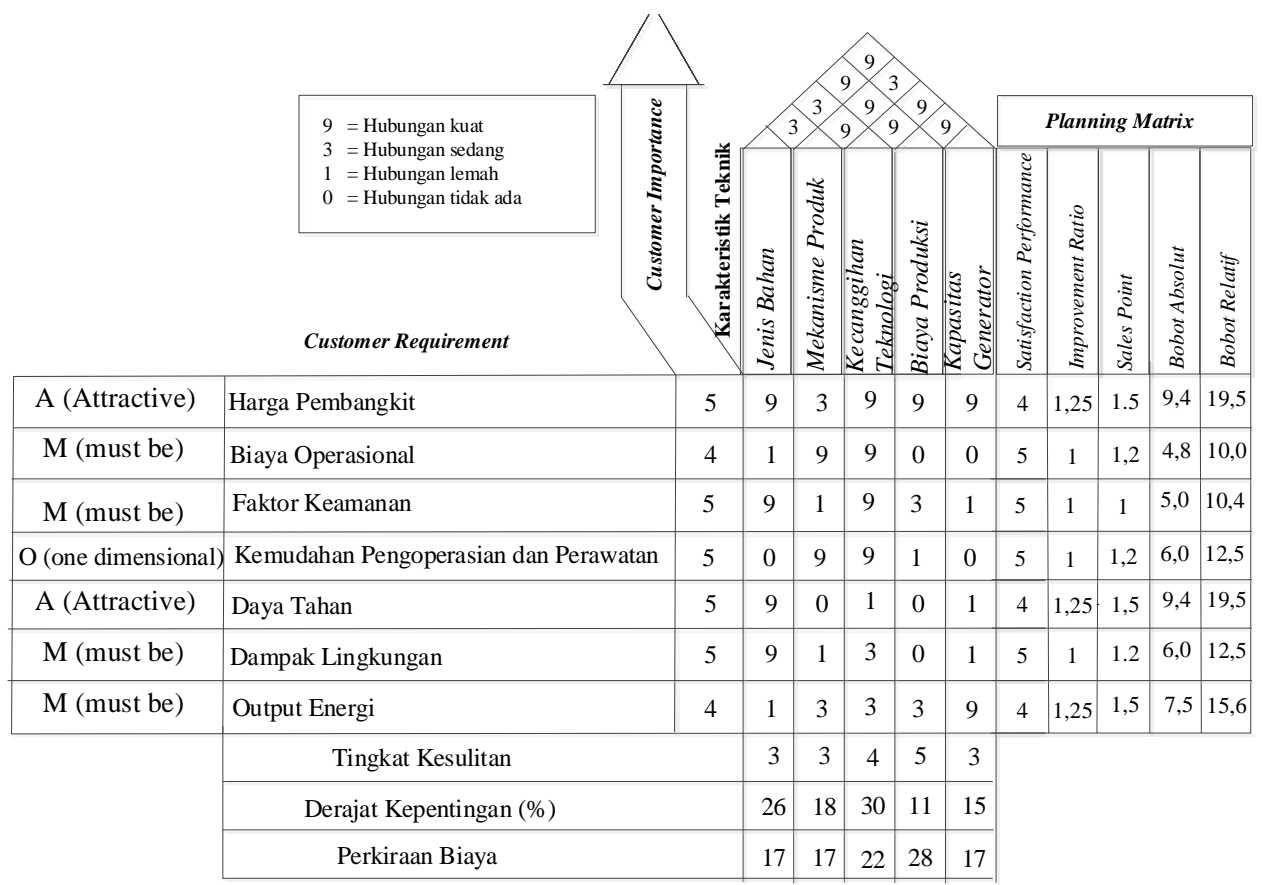

Figure 3. Matrix House of Alternative Power Generation 
The results of the QFD phase I show that the most important characteristics to be immediately improved are technological sophistication and production costs with the highest degree of importance, difficulty, and estimated cost. The planning matrix shows the product attributes in the form of generating prices and durability are priority improvements due to the highest weight.

Technical characteristics that have the highest to the lowest degree of importance are technology sophistication, material type, product mechanism, generator capacity, and production costs. Based on the results of data processing, it can be arranged the needs of the design of energy generating equipment, as follows:

1. Solar-based electricity generation

2. Easy to use and maintain

3. Affordable prices

4. Has a long endurance

5. Consists of several basic components as follows
a. Solar Panel
b. Solar Charge Controller
c. Battery
d. Lamp

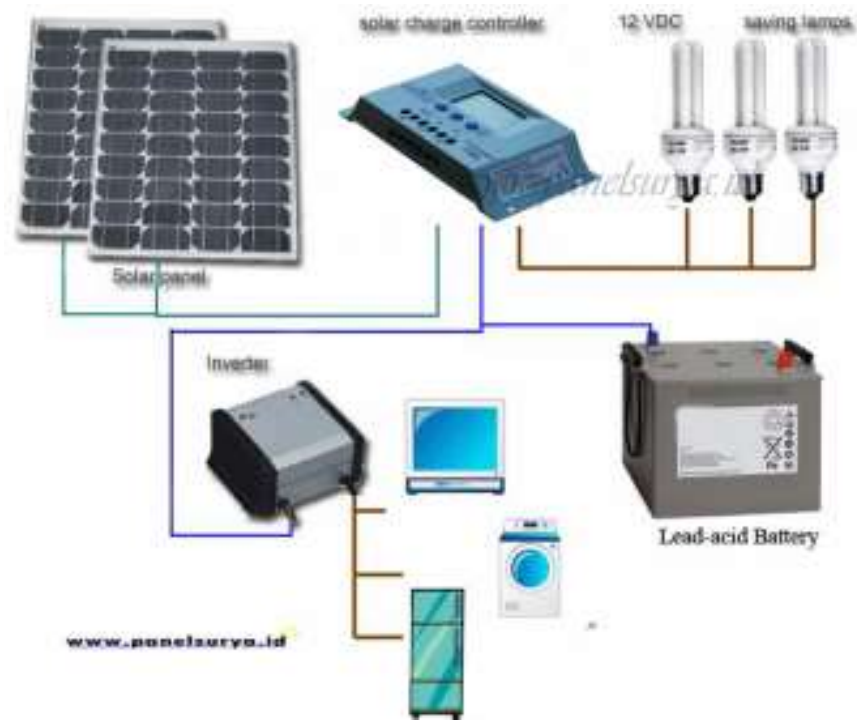

Figure 4. Need of Generator Design Equipments

\section{Kano Analysis}

Kano questionnaires processed to determine the categories of each attribute based on the Kano model. The results then calculated on the number format or value of each Kano on each attribute to all respondents. The number of each categories of each attribute determines, using Blauth's formula.

1. The number of values (one dimension + attractive + must be) $>$ the total value (indifferent + reverse + questionable) then the grade obtained is the maximum value of (one dimensional, attractive, must be).

2. The number of values (one dimensional + attractive + must be) <number of values (indifferent + reverse + questionable) then the grade obtained is the maximum value of (indifferent, reverse, questionable).

3. Number of values (one dimension + attractive + must be) $=$ total value (indifferent + reverse + questionable) then graded is the maximum value among all categories of Kanos (one dimensional, attractive, must be and indifferent, reverse, questionable) . 
Table 2 shows the results of the calculation and classification of Kano analysis that used for mapping the categories of each Customer attribute (CR).

Table 2. Kano Category Mapping of Each Attribute

\begin{tabular}{clcccccc}
\hline \multirow{2}{*}{ No } & \multirow{2}{*}{ Atribut } & A & O & M & I & R & Q \\
\cline { 3 - 8 } & & 10 & 3 & $\mathbf{1 2}$ & 10 & 0 & 0 \\
\hline 1 & Operation cost & 7 & 5 & $\mathbf{1 0}$ & 11 & 2 & 0 \\
2 & Safety factor & 6 & 1 & $\mathbf{1 2}$ & 13 & 3 & 0 \\
3 & Output of Energy & $\mathbf{1 1}$ & 4 & 6 & 12 & 2 & 0 \\
4 & Price of Generator & $\mathbf{1 0}$ & 5 & 9 & 9 & 0 & 2 \\
5 & Durability & 7 & $\mathbf{1 1}$ & 7 & 8 & 2 & 0 \\
6 & Ease of Operation & 4 & 10 & $\mathbf{1 1}$ & 10 & 0 & 0 \\
7 & Enviromental Impact & 2 & 10 & 4 & $\mathbf{1 9}$ & 0 & 0 \\
8 & Aesthetics & & & & & & \\
\hline
\end{tabular}

Next phase determines the Kano category by using Blauth's formula. For example, for attribute 1 (one dimensional + attractive + must be) $=10$ and (indifferent + reverse + questionable) $=5$, then the Kano category for attribute 1 is Attractive (A). Table 3 shows the recapitulation of Kano category.

Table 3. Mapping Each Attribute According to Blauth's formula

\begin{tabular}{clc}
\hline No & \multicolumn{1}{c}{ Atribut } & Kategori Kano \\
\hline 1 & Operation cost & $\mathrm{M}$ \\
2 & Safety factor & $\mathrm{M}$ \\
3 & Output of Energy & $\mathrm{M}$ \\
4 & Price of Generator & $\mathrm{A}$ \\
5 & Durability & $\mathrm{A}$ \\
6 & Ease of Operation & $\mathrm{O}$ \\
7 & Enviromental Impact & $\mathrm{M}$ \\
8 & Aesthetics & $\mathrm{I}$ \\
\hline
\end{tabular}

Table 3 shows two attributes in the attractive category, one attribute in one dimension, and 4 attributes in must be categorized. Meanwhile, one attribute lies in indifferent. Aesthetic attributes are categorized as indifferent. It means that we can eliminate these attributes. While the designer may focus more on the attributes of ease of operation and durability, because of both attributes categorized as one dimensional. It is a normal requirement of customer demands, where the higher the product functionality is quality, the highest customer satisfaction. The attributes are categorized as indifferent can be excluded from the next step.

\section{Calculates CS and DS}

CS recognizes that customer satisfaction will increase if the company meets the customer needs (CR). On the other hand, DS (customer satisfaction) identify that Customer dissatisfaction will increase if the customer expectations not fulfilled.

The calculation of CS and DS values use the following formulas:

$$
\begin{aligned}
C S_{i} & =\frac{f_{A}+f_{o}}{f_{A}+f_{o}+f_{M}+f_{I}} \\
D S_{i} & =-\frac{f_{o}+f_{M}}{f_{A}+f_{o}+f_{M}+f_{I}}
\end{aligned}
$$

where:

$\mathrm{f}_{\mathrm{a}}=$ the number of Customer responses choose attractive

$\mathrm{f}_{\mathrm{o}}=$ the number of Customer responses choose one-dimensional

$\mathrm{f}_{\mathrm{m}}=$ the number of Customer responses choose atribut must-be 
$\mathrm{f}_{\mathrm{i}}=$ the number of Customer responses choose indifferent.

Following are the CS and DS values for Attribute 1:

$$
\begin{aligned}
& \mathrm{CS}_{1}=\frac{10+3}{10+3+12+10}=0.371 \\
& \mathrm{DS}_{1}=-\frac{3+12}{10+3+12+10}=-0.429
\end{aligned}
$$

The same method is used for the calculation of each category. Table 4 shows the CS and DS values for the attributes of the customer from 2 to 7.

Table 4. Determination of CS and DS Values for Each Attribute

\begin{tabular}{llcccccccc}
\hline \multirow{2}{*}{ No } & \multirow{2}{*}{ Attribute } & \multicolumn{9}{c}{ Kano Category } & \multirow{2}{*}{ Cs } & \multirow{2}{*}{ Ds } \\
\cline { 3 - 8 } & & $\mathbf{A}$ & $\mathbf{O}$ & $\mathbf{M}$ & $\mathbf{I}$ & $\mathbf{R}$ & $\mathbf{Q}$ & & \\
\hline 1 & Operation cost & 10 & 3 & $\mathbf{1 2}$ & 10 & 0 & 0 & 0,371 & $-0,429$ \\
2 & Safety factor & 7 & 5 & $\mathbf{1 0}$ & 11 & 2 & 0 & 0,364 & $-0,455$ \\
3 & Output of Energy & 6 & 1 & $\mathbf{1 2}$ & 13 & 3 & 0 & 0,219 & $-0,406$ \\
4 & Price of Generator & $\mathbf{1 1}$ & 4 & 6 & 12 & 2 & 0 & 0,455 & $-0,303$ \\
5 & Durability & $\mathbf{1 0}$ & 5 & 9 & 9 & 0 & 2 & 0,455 & $-0,424$ \\
6 & Ease of Operation & 7 & $\mathbf{1 1}$ & 7 & 8 & 2 & 0 & 0,545 & $-0,545$ \\
7 & Enviromental Impact & 4 & 10 & $\mathbf{1 1}$ & 10 & 0 & 0 & 0,400 & $-0,600$ \\
\hline
\end{tabular}

\section{Determine the CS and DS Points}

Based on Table 4, it can be seen that the CS and DS values obtained from the Kano questionnaire can be used further to determine the CS and DS points. The two CS and DS points for each attribute of the customer's wish can be expressed as (1, CSi) which is the customer's satisfaction when the customer requirement attribute is fully satisfied which means that the fulfillment of the customer's attribute attribute level is equal to 1 . The CS point can be expressed as $(0, \mathrm{DSi})$, which is a customer's dissatisfaction when the customer's desire attribute is unavailable, which means that the fulfillment of the customer's desire attribute level is equal to 0 .

Example: first Customer desire attributes

$$
\begin{aligned}
& \mathrm{CS}_{1}=0.371 \\
& \mathrm{DS}_{1}=-0.429
\end{aligned}
$$

CS and DS points can be specified $(1,0.371)$ dan $(0,-0.429)$

Table 5 shows the determination of the CS and DS values for each of the other customer's desired properties.

Table 5. Determination of CS and DS Values for Each Attribute

\begin{tabular}{cccccc}
\hline CR & $\begin{array}{c}\text { Kano } \\
\text { Category }\end{array}$ & CS & DS & $\begin{array}{c}\text { CS Point } \\
\left(\mathbf{1}, \mathbf{C S}_{\mathbf{i}}\right)\end{array}$ & $\begin{array}{c}\text { DS Point } \\
\left(\mathbf{O , D S}_{\mathbf{i}}\right)\end{array}$ \\
\hline 1 & M & 0.371 & -0.429 & $(1,0.371)$ & $(0,-0.429)$ \\
2 & $\mathrm{M}$ & 0.364 & -0.455 & $(1,0.364)$ & $(0,-0.455)$ \\
3 & $\mathrm{M}$ & 0.219 & -0.406 & $(1,0.219)$ & $(0,-0.406)$ \\
4 & $\mathrm{~A}$ & 0.455 & -0.303 & $(1,0.455)$ & $(0,-0.303)$ \\
5 & $\mathrm{~A}$ & 0.455 & -0.424 & $(1,0.455)$ & $(0,-0.424)$ \\
6 & $\mathrm{O}$ & 0.545 & -0.545 & $(1,0.545)$ & $(0,-0.545)$ \\
7 & $\mathrm{M}$ & 0.400 & -0.600 & $(1,0.400)$ & $(0,-0.600)$ \\
\hline
\end{tabular}




\section{Define the Customer Satisfaction Function}

The next step is to measure the relationship between customer satisfaction (S) and customer satisfaction (CR) with the corresponding equation. In general, the S-CR relation function for each attribute can be expressed as so $=\mathrm{f}(\mathrm{Yi}, \mathrm{a}, \mathrm{b})$ where the individual represents the level of individual customer satisfaction derived from the customer's desire, i.e. the customer's satisfaction level from 0 to 1 and a, b is the adjustment category of the different categories of CRs.

The equation functions for CSR relationships based on Kano categories.

\section{Attractive}

The equations of the customer satisfaction for interesting categories are as follows:

$$
\begin{aligned}
& s_{i}=a_{2} e^{y_{i}}+b_{2} \\
& a_{2}=\frac{C S_{i}-D S_{i}}{e-1} \quad b_{2}=\frac{C S_{i}-e D S_{i}}{e-1} \\
& S_{i}=\frac{C S_{i}-D S_{i}}{e-1} e^{y_{i}}+\frac{C S_{i}-e D S_{i}}{e-1}
\end{aligned}
$$

Meanwhile, equation for attribute 4:

$$
\begin{aligned}
& \mathrm{a}_{1}=\frac{0.455-(-0.303)}{2.718-1}=0.441 \\
& \mathrm{~b}_{1}=\frac{0.455-(2.718)(-0.303)}{2.718-1}=0.728
\end{aligned}
$$

The customer satisfaction function equation for attribute 4 is:

$$
\mathrm{S}_{4}=0.441 \mathrm{e}^{\mathrm{y} 4}-0.728
$$

The same method is used so that the customer satisfaction equation for attribute 5 is interesting, that is:

$$
\mathrm{S}_{5}=0.512 \mathrm{e}^{\mathrm{y} 5}-0.918
$$

\section{One Dimensional}

The equation of the customer satisfaction function for the One Dimensional category is as follows:

$$
\begin{aligned}
& a_{1}=C S_{i}-D S_{i} \quad b_{1}=D S_{i} \\
& S_{i}=\left(C S_{i}-D S_{i}\right) y_{i}+D S_{i}
\end{aligned}
$$

The equation function for attribute 6 :

$$
\begin{aligned}
& \mathrm{a}_{6}=0.545-(-0.545)=1.091 \\
& \mathrm{~b}_{6}=-0.545
\end{aligned}
$$

The equation of the Customer The equation function for attribute 6 is as follows:

$$
\mathrm{S}_{6}=1.091 \mathrm{y}_{6}-0.545
$$

\section{Must Be}

The equation of the customer satisfaction function for the Must Be category is as follows:

$$
a_{1}=\frac{e\left(C S_{i}-D S_{i}\right)}{e-1} b_{1}=\frac{e C S_{i}-D S_{i}}{e-1}
$$




$$
S_{i}=\frac{e\left(C S_{i}-D S_{i}\right)}{e-1} e^{-y_{i}}+\frac{e C S_{i}-D S_{i}}{e-1}
$$

Fungsi persamaan untuk atribut 1:

$$
\begin{aligned}
& \mathrm{a}_{1}=\frac{2.718((0.371-(-0.429))}{2.718-1}=1.266 \\
& \mathrm{~b}_{1}=\frac{2.718(0.371)-(-0.429)}{2.718-1}=0.837
\end{aligned}
$$

The Customer satisfaction equation for attribute 1 is:

$$
\mathrm{S}_{1}=1.266 \mathrm{e}^{-\mathrm{y} 1}+0.837
$$

The same method is used so that the customer satisfaction equations for the 2, 3 and 7 attributes are categorized as follows:

$$
\begin{aligned}
& S_{2}=1.294 \mathrm{e}^{-\mathrm{y} 2}+0.840 \\
& \mathrm{~S}_{3}=0.989 \mathrm{e}^{-\mathrm{y} 3}+0.583 \\
& \mathrm{~S}_{7}=1.582 \mathrm{e}^{-\mathrm{y} 7}+0.982
\end{aligned}
$$

Table 6 shows the function of the customer satisfaction equation for three attractive, onedimensional, and must-see category, as follows:

Table 6. Fungsi Kepuasan Konsumen untuk Tiap Atribut

\begin{tabular}{clcl}
\hline No & \multicolumn{1}{c}{ Attribute } & $\begin{array}{c}\text { Kano } \\
\text { Category }\end{array}$ & \multicolumn{1}{c}{$\mathbf{S} \mathbf{i}=\mathbf{a} \mathbf{f}(\mathbf{y})+\mathbf{b}$} \\
\hline 1 & Operation cost & $\mathrm{M}$ & $\mathrm{S}_{1}=1.266^{-\mathrm{y} 1}+0.837$ \\
2 & Safety factor & $\mathrm{M}$ & $\mathrm{S}_{2}=1.294^{-\mathrm{y} 2}+0.840$ \\
3 & Output of Energy & $\mathrm{M}$ & $\mathrm{S}_{3}=0.989^{-\mathrm{y} 3}+0.583$ \\
4 & Price of Generator & $\mathrm{A}$ & $\mathrm{S}_{4}=0.441 \mathrm{e}^{\mathrm{y} 2}+0.728$ \\
5 & Durability & $\mathrm{A}$ & $\mathrm{S}_{5}=0.512 \mathrm{e}^{\mathrm{y} 5}+0.918$ \\
6 & Ease of Operation & $\mathrm{O}$ & $\mathrm{S}_{6}=1.091 \mathrm{y}_{6}-0.545$ \\
7 & Enviromental Impact & $\mathrm{M}$ & $\mathrm{S}_{7}=1.582 \mathrm{e}^{-\mathrm{y} 7}+0.982$ \\
\hline
\end{tabular}

\section{Plotting the curve function of customer satisfaction}

Plotting Curve of customer satisfaction functions for each attribute category:

\section{Attractive}

a) Attribute: Price of generator.

The equation function:

$\mathrm{S}_{4}=0.441 \mathrm{e}^{\mathrm{y} 4}-0.728$

Steps for create a plot diagram are described as follows:

$$
\begin{array}{ll}
\mathrm{y}=0.05 & \rightarrow \mathrm{S}=1.192 \\
\mathrm{y}=0.2 & \rightarrow \mathrm{S}=1.269 \\
\mathrm{y}=0.5 & \rightarrow \mathrm{S}=1.464 \\
\mathrm{y}=1 & \rightarrow \mathrm{S}=1.467
\end{array}
$$

Figure 5 shows the graph of the customer satisfaction The equation function for Attribute 4, Price Generator. 


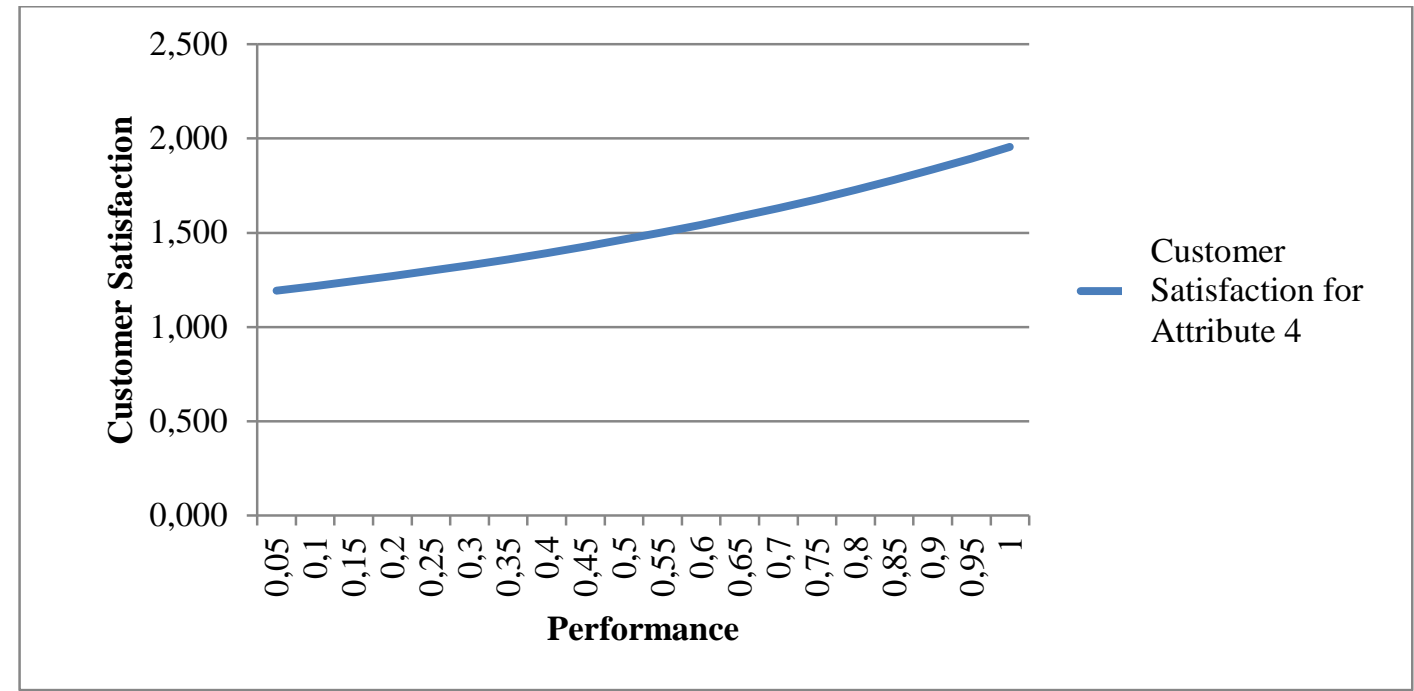

Figure 5. Customer Satisfaction Function Curve for Generator Attribute Prices

b) Durability

The equation function:

$\mathrm{S}_{5}=0.512 \mathrm{e}^{\mathrm{y} 5}+0.918$

Figure 6 shows a graph of the customer satisfaction The equation function for Attribute 5, i.e. durability.

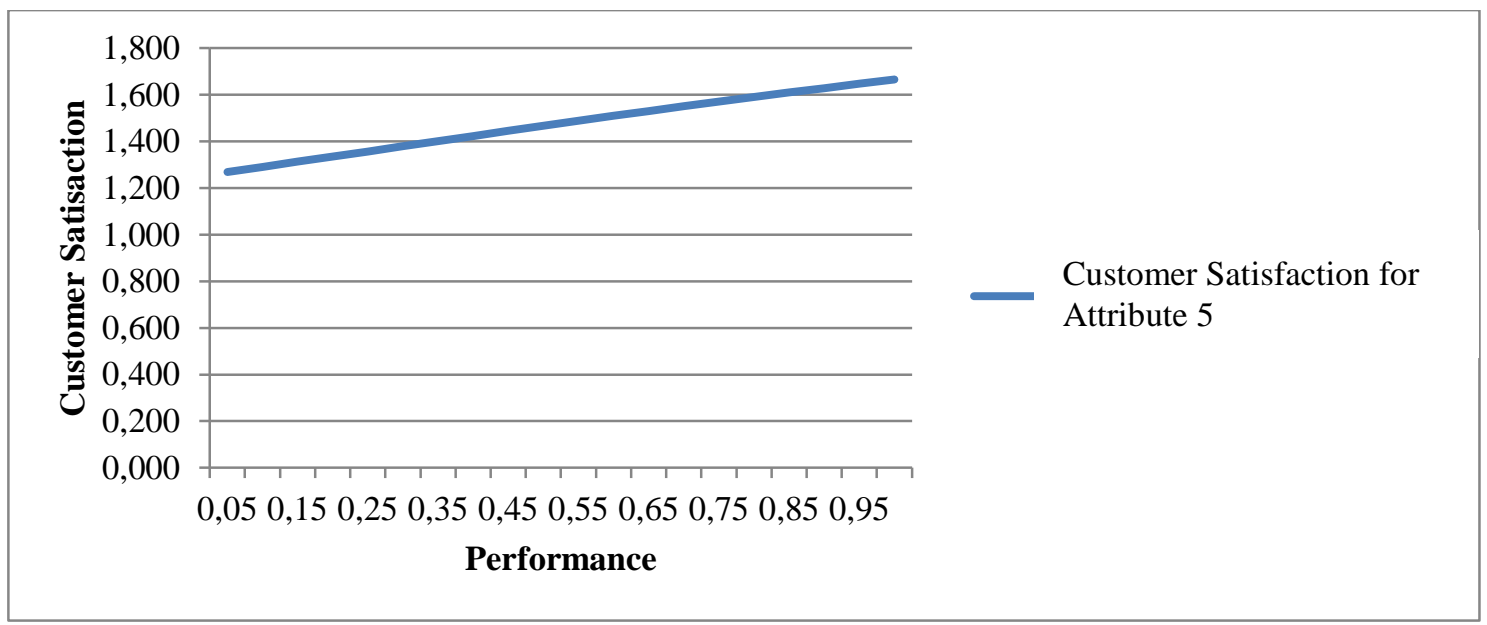

Figure 6. Satisfaction Function of Customer Satisfaction for Resilience Sensitivity

\section{Kategori One Dimensional}

a) Attribute of ease of operation

The equation function:

$\mathrm{S}_{6}=1.091 \mathrm{y}_{6}-0.545$

Figure 7 shows the function of the customer satisfaction equation for Attribute 6, Operating Facility. 


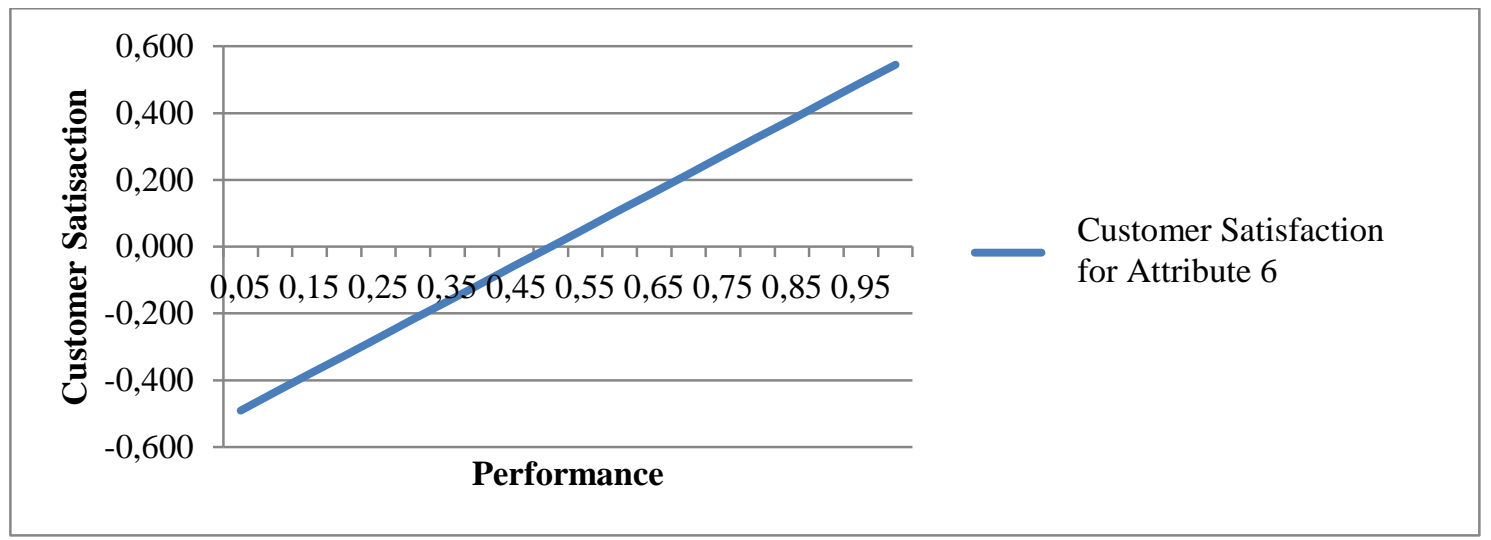

Figure 7. Customer Satisfaction Function Curve for Operating Attribute Ease

\section{Must Be}

a) Attribute of operation cost

The equation function:

$\mathrm{S}_{1}=1.266^{-\mathrm{y} 1}+0.837$

Figure 8 shows the function curve of the customer satisfaction equation for attribute 1, i.e. Operating cost.

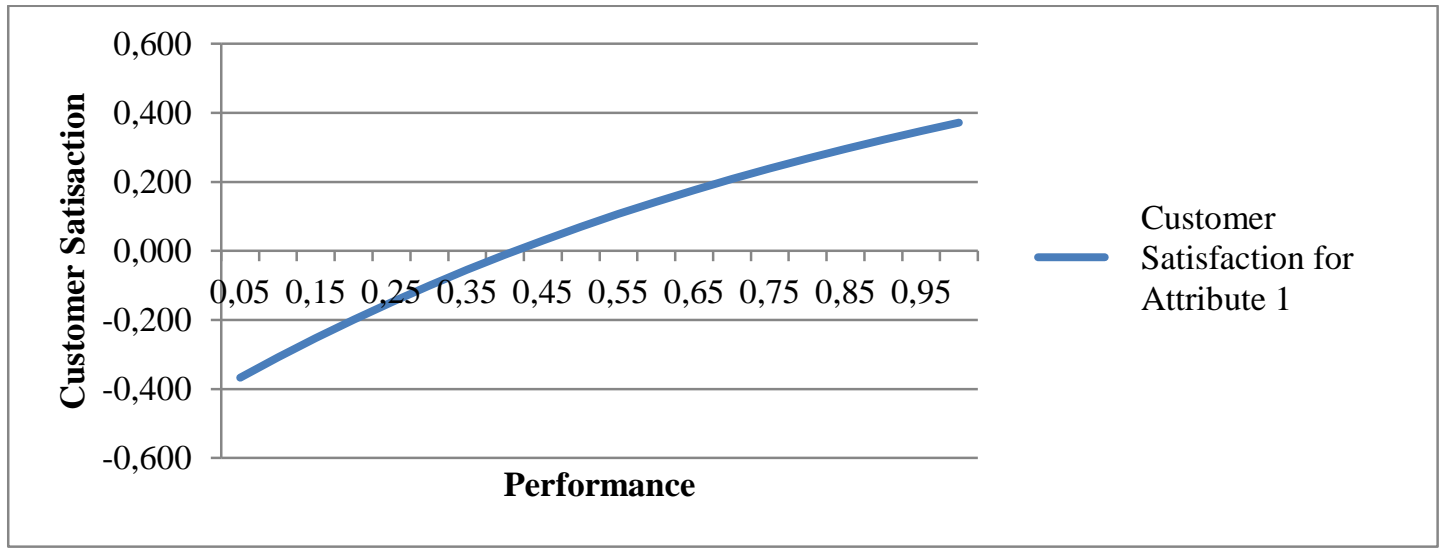

Figuer 8. The Customer Satisfaction Function Curve for the Operation cost attribute

b) Attribute of safety factor

The equation function:

$\mathrm{S}_{2}=1.294^{-\mathrm{y} 2}+0.840$

Figure 9 shows the function curve of the Customer satisfaction equation for attribute 2, i.e. Safety factor. 


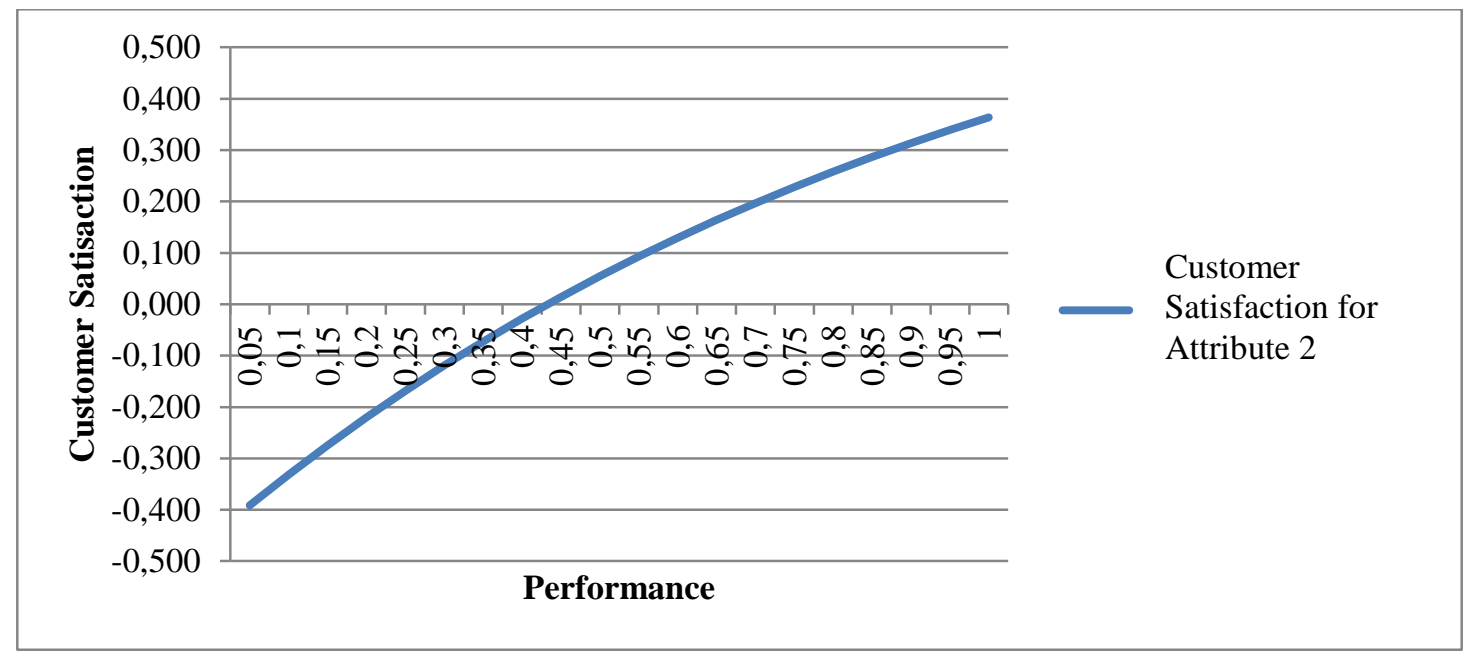

Figure 9. Customer Satisfaction Function Curve for Safety factor

c) Atribut Output of Energy

The equation function:

$\mathrm{S}_{3}=0.989^{-\mathrm{y} 3}+0.583$

Figure 10 shows the function curve of the Customer satisfaction equation for Attribute 3, i.e. output of Energy.

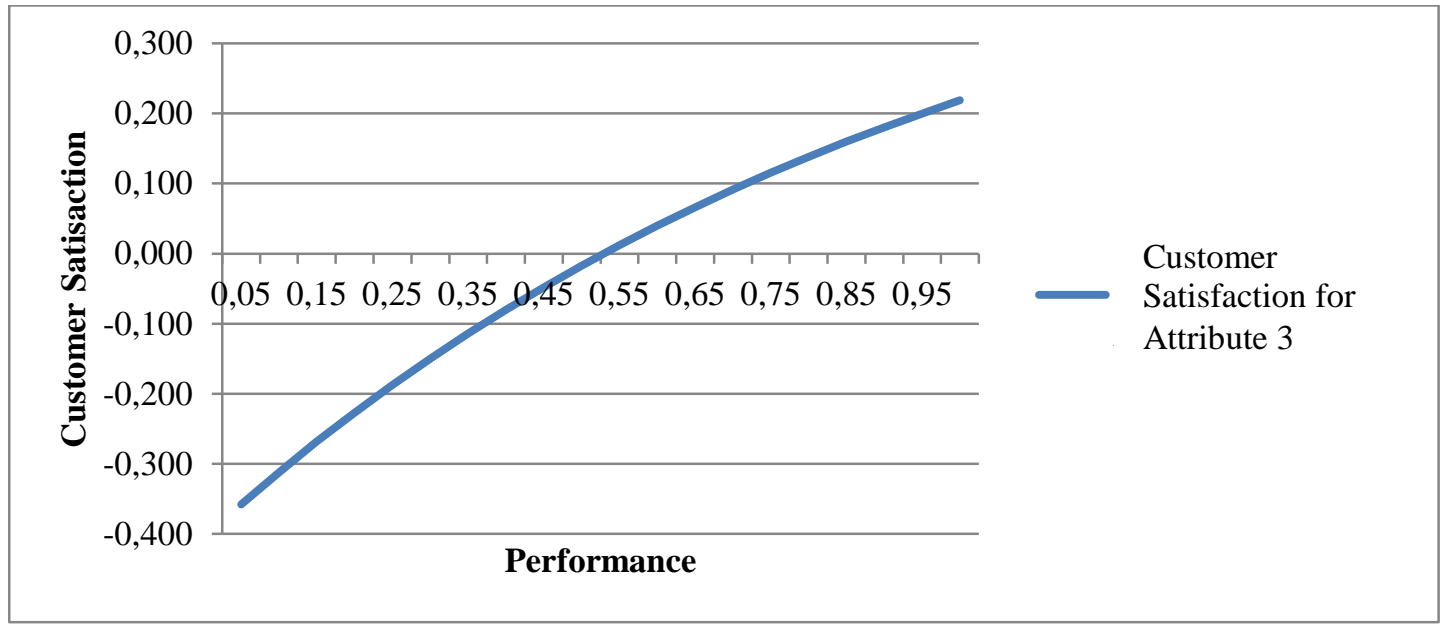

Figure 10. The Customer Satisfaction Function Curve for the Output of Energy Attribute

d) Attribute of enviromental impact

The equation function:

$\mathrm{S}_{7}=1.582^{-\mathrm{y} 7}+0.982$

Figure 11 shows the function curve of the consumer satisfaction equation for Attribute, i.e. enviromental impact. 


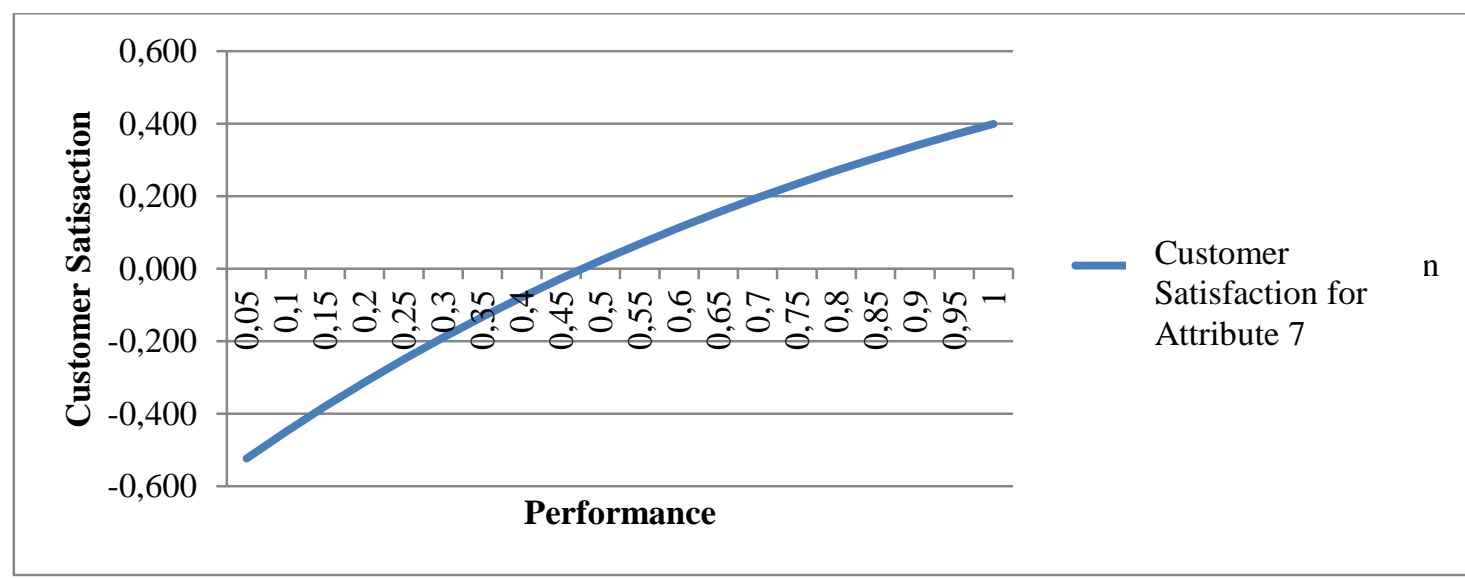

Figure 11. The Customer Satisfaction Function Curve for Environmental Impact Attributes

\section{Conclusion}

From the Kano survey, it was found that one attribute is in the Interesting category, two attributes were in the One dimension category, and four attributes were in the Must category. By looking at the Canoe category for each attribute, manufacturers can prioritize product development. For example, properties that fall into the category must be better if not further developed with high investment. This is because these traits are a must. It's best to develop properties in one-dimensional categories. Although attributes that fall into the category Suddenly means that the development of these attributes will not have much impact on customer satisfaction. Through the use of the Kano questionnaire, manufacturers can eliminate attributes for further processing, and focus on developing key attributes for customers.

\section{ACKNOWLEDGEMENT}

This study was funded by Directorate of Research and Community Service, Directorate General for Research and Development at the Ministry of Research, Technology and Higher Education of Indonesia.

\section{REFERENCES}

[1]. WHO Statistics [Cited 2015] World Health Statistics 2014 [Internet] available from http://who.int/gho/publications/world_health_statistics/2014/en/

[2] UNICEF statistics on Infant Mortality Rates: Available at http://www.childinfo.org/cmr/revis/db1.htm

[3] Mkongwa, Kefa G; Mbuya, Benson; Mbelwa, Masudi.2017 Novel approach to inverse problems for pre mature and infants' incubators. International Journal of Bioengineering and Technology; Coimbatore, vol. 6, no. 2, pp 13-17.

[4] Kano, Noriaki, et al. 1984. 'Attractive quality and must-be quality', Journal of the Japanese Society for Quality Control, vol. 14, no.2, pp 39-48.

[5] Sreenath S. N., Sudhindra Kumar, Lohit H. S. 2012. Design of an Infant Incubator for Cost Reduction and Improved Usability for Indian Health Care Centers. SASTECH Journal vol. 11, no. 2, Sep 2012, 82-89

[6] Shaemi Barzoki, Ali \& Salehzadeh, Reza \& Ahmad KHODAEI, Sayyed. (2014). Identifying Attractive Behaviors of Managers Based on Kano Model in Isfahan Province Gas Company. International Journal of Academic Research in Accounting, Finance and Management Sciences. vol. 4, no.1, pp. 16-20. doi:10.6007/IJARAFMS/v4-i1/504.

[7] Q. Meng, N. Zhou, J. Tian, Y. Chen and F. Zhou. 2011. Analysis of Logistics Service Attributes Based on Quantitative Kano Model: A Case Study of Express Delivering Industries in China. Journal of Service Science and Management, vol. 4, no.1, pp. 42-51. doi: 10.4236/jssm.2011.41007. 